\title{
Stakeholder Perspective of Corporate Governance and CSR Committees*
}

\author{
Daniela M. Salvioni ${ }^{* *}$ Francesca Gennari ${ }^{* * *}$
}

\begin{abstract}
CSR is becoming more and more important, and many companies have taken meaningful steps to improve their corporate governance according with a stakeholder perspective. An emerging board-level figure is the CSR or sustainability committee. The increase in complexity induced by the responsible business conduct and the growing importance of the effective management of reputational risk, highlight the usefulness of committees with proposing and consultative functions on CSR issues. These committees are relatively new governance structures, whose affirmation is slow, and can provide a useful contribution to the integration of social responsibility into strategy setting and the business model.
\end{abstract}

Keyword: Corporate Governance; Stakeholder Theory; Responsible Business Conduct; CSR Committees; Corporate Sustainability; Global Markets

\section{CSR and Stakeholder Perspective}

The great attention economic environment is paying to corporate social responsibility (CSR) has led many companies to improve their corporate governance according with a stakeholder perspective. In fact, the company's ability to manage a network of relationships with stakeholders is becoming a driver of sustainable development in the long-run and a basis for a long-lasting competitive advantage, thanks to the creation of a win-win situation for company, stakeholders, and society (Elkington, 1994; Kolk \& Pinkse, 2007; Dima, 2008).

The engagement with stakeholders and the climate-resilient development strategies are increasingly emerging as essential factors for firms' success. The potential to optimize results over time depends on the valorisation of stakeholders' expectations. The ability to activate positive stakeholder engagement processes has become a prerequisite for the nurturing of virtuous circles, based on the joint relations among resources, activities, achievements and consensus considering the greater risk factors which influence firms' operations and the increasing complexity of direct and mediated relationships between firms and markets (Salvioni, 2018).

The interaction with stakeholders ensures a better understanding of the firm's expectations, its priorities and related prospective changes, facilitating the adoption

\footnotetext{
${ }^{*}$ The Authors: Salvioni, D.M. $\S 1,4$, Gennari, F. $\S ~ 2,3$

** Full Professor of Business Administration, University of Brescia (daniela.salvioni@ unibs.it)

**** Associate Professor of Business Administration, University of Brescia (francesca.gennari@unibs.it)
}

Salvioni, D.M. \& Gennari F. (2019). Stakeholder Perspective of Corporate Governance and CSR Committees, Symphonya. Emerging Issues in Management (symphonya.unicusano.it), 1, 28-39. 
of social responsibility-oriented strategies and integrating economic, social, and environmental performance. Therefore, the corporate governance extends to the system of relationship of confidence with stakeholders, managing the business in responsible and transparent way for the creation of shared value (Porter \& Kramer, 2011), the obtaining of resources, the financial stability and the sustainable growth.

The creation of shared value, pursuing corporate success in a way that also yields societal benefits, has become an imperative for companies, which are persuaded to put their efforts in bringing together the various actors in their ecosystems (Kramer \& Pfitzer, 2016).

From time to time, scholars emphasised different categories of key stakeholders underlining the shareholder-centred approach to corporate governance or the stakeholder-perspective one. The emergence of the concepts of corporate social responsibility and sustainable development has undoubtedly shown the limits inherent in the excessive focus on the shareholder view, promoting the diffusion of the stakeholder perspective (Freeman, 1984). Furthermore, the growing awareness of the risk reduction and the creation of long-term stability conditions connected to socially responsible corporate behaviour are reflected in the reconciliation of the interests of stakeholders corresponding to the property (firms' owners or shareholders) with those of other stakeholders (non-owner stakeholders) (Salvioni \& Gennari, 2017; Salvioni, 2018).

The extension of wide categories of relevant stakeholders led companies to run their corporate governance with the aim to achieve their mission respecting the conditions of effectiveness, efficiency and sustainable development. The integration of CSR into different aspects of business is possible adjusting the decision-making processes and activities with the satisfaction of stakeholders' expectations, providing an integrated reporting system that aim at combining socioenvironmental and financial aspects, addressing the CSR along the supply chain (Visser \& Kymal, 2015; Mosca \& Civera, 2017; Bosetti, 2018).

Therefore, a world characterized by the interconnectedness of global economy and the growing attention for socio-environmental issues, together with the economic ones, within strategies and operations encourages companies to engage in their sustainable development. This way of doing business requires an improvement of corporate governance in order to:

- move toward a greater convergence between different corporate governance systems, promoting the catching of resources at global level (Salvioni et al., 2016);

- give value to the relationships among different performance drivers, emphasising the risk management system for an effective responsible business conduct (OECD, 2018). The attitude by companies to shift from risks' mitigation to risks' active management benefits the company business and reputation helping it to build solid relationships with stakeholders (Cini \& Ricci, 2018);

- develop strategies and accountability tools supporting stakeholder engagement and transparency in the communication of corporate performance (Salvioni \& Bosetti, 2014; AccountAbility, 2015);

- engage shareholders for the value creation over time. The empowerment of shareholders in board decision-making can improve the company's capital 
allocation process and strategy to find the right balance between short-term results requirement and long-term value creation (Salvioni \& Gennari, 2017).

It follows that corporate governance is becoming more complicated, requiring a continuous assessment of the critical success factors, related strategic choices, key performance indicators, and accountability tools. In particular, strategies could suffer the risk related to potential trade-offs among wide and different stakeholder expectations in a world where resources are limited; actually, they are false dichotomies considering that company has a global responsibility due to interdependence among all stakeholders (Freeman \& Dmytriyev, 2017).

Stakeholder theory posits that the essence of business primarily lies in building value-adding relationships. Individual companies are increasingly part of an ecosystem of sustainable development relations influencing corporate strategies, corporate culture and corporate performance.

Be part of a dynamic network of relationships requires corporate top level positions equipped to handle the management of this new and increasing complexity.

The corporate approach to sustainable value creation, based on stakeholder perspective of business, needs a coherent leadership behaviour by board of directors, that should set up processes and business models globally responsible and sustainable at their core, ensuring sustainability issues are integrated into corporate strategies and objectives (Gorenak \& Bobek, 2010; Del Baldo, 2017; Mosca \& Civera, 2017; Bocean et al., 2018).

According with several authors (Eccles et al., 2011; Willard, 2012; Miller \& Serafeim, 2014) the path toward sustainability consists of sequential stages characterized by different corporate governance structure with particular reference to the positions devoted to the management of sustainability issues. In the first stage, the focus is on compliance with external and internal regulations; moreover, sustainability is not considered as a strategy requiring central management and there is no formal sustainability position. The next stage is marked by a more strategic approach to sustainability, putting emphasis on how to achieve organisational efficiencies by engaging internal stakeholders too. There can be a special position devoted to sustainability (as Chief Sustainability Officer), even if the ultimate responsibility for sustainability is attributed to the Chief Executive Officer. The last stage is the most proactive and it is characterized by sustainabilitydriven strategies discussed in special committees within the board.

In general, the establishment of board committees concerns the management of sensitive issues because of related to critical success factors and/or sources of potential conflicts of interest. In addition to the most common committees (audit, nomination, and compensation), special committees devoted to corporate social responsibility (CSR) and sustainability are spreading to support the board in strategies characterized by the close relationship among competitive, economic and socio-environmental success' conditions. These are relatively new governance structures, which can provide a useful contribution to the integration of social responsibility into strategy setting and into the business model.

Basing on the previous considerations, the article is structured as follows. Sec. 2 highlights the importance of corporate governance for the responsible business conduct; Sec. 3 aims at going in-depth the CSR committees, with a special focus on 
the European area. The final session discusses the importance of having appropriate board structures for stakeholder engagement and the management of the risk of responsibility failures.

\section{Corporate Governance and Responsible Business Conduct}

The principle of responsible business conduct (RBC) implies the corporate global responsibilities towards stakeholders that is managing risks and performance according with the triple bottom line approach (Elkington, 1998) including economic, social and environmental business perspectives.

The epochal scandals and financial crises made clear the gap between companies performance and their deep corporate values, and led to a re-evaluation of a new corporate model in which responsible corporate culture puts greater emphasis on integrity and trust (Byrne, 2000).

The management of business according with the RBC requires the commitment of the corporate governance bodies, which define strategies and related acceptable risks, plan goals, develop internal codes of conduct and control systems. In other words, the corporate governance structures and processes significantly influence the $\mathrm{RBC}$, in order to put together the expectations of all stakeholders, shareholders included.

Shareholders have always had a significant role in the attribution of the mandate of corporate governance, and this fact induced the corporate governance choices were characterized by profit maximisation. The arise of new concepts referring to sustainability, social responsibility and stakeholder relation management is inducing a new approach about the role of companies in society, with clear consequences in terms of strategic choices and performance, also for shareholders. Corporate sustainability does not mean that the creation of value and the adequate remuneration for shareholders are less important; vice versa, the interdependence among the stakeholder relation management, the economic and socioenvironmental responsibility, the results (economic and not economic ones), the capability to obtain consents and resources is opportunely emphasised for all stakeholders' interests (Salvioni \& Astori, 2013; Salvioni \& Gennari, 2016).

This integrated business approach nurtures the creation of trust relationships with financial markets, society, and stakeholders in general in order to manage the corporate reputational risk in the best way. Corporate reputation is a multistakeholder concept that is reflected in the perception that stakeholders have of an organisation diversely interacting with different stakeholders (Baldarelli \& Gigli, 2014). Hence, companies when managing their reputation should take into account not only their relationships with stakeholders, but also how stakeholders influence each other (Dutton \& Dukerich, 1991).

The reputational risk results from the connection between reputational drivers and risk factors. Reputational drivers convey the stakeholders' expectations on which company can operate to improve its reputation. A strong reputation can be a key competitive asset (Barnett et al., 2006), which is especially important in today's environment of increasing competition, deregulation, globalization and almost instantaneous flow of information (Alfiero et al., 2016). Risk factors are connected 
with the way reputational drivers are managed in order to control the reputational risk that is created when corporate performance does not match stakeholders' expectations. The ability by company to manage expectations and performance related to its reputation by means of transparency in behaviours, accountability, and stakeholders engagement determines the creation of value in the long-run.

From a stakeholder perspective, corporate responsibility is a part of a wider context of the corporate relationships with stakeholders (Neville et al., 2005). For this reason, the criteria to define and measure reputation, as responsibility, should be object of a process of continuous consultation with stakeholders (Jones, 1995; Wood et al., 2006).

The strategic awareness of the importance of corporate reputation is more critical when key stakeholders are numerous, because of the reputational drivers expand in socio-economical drivers and socio-environmental ones, depending on business' characteristics and influencing industry's conduct. Well-defined RBC and CSR activities ensure the optimum balance among social, environmental, and economic factors for short and long-term profit sustainability. It is important to emphasise that corporate responsibility and corporate reputation should reside on the corporate governance level (Baldarelli \& Gigli, 2011) and from this level should be spread into managerial and organisational positions.

The increase in complexity induced by the RBC and the growing importance of the effective management of reputational risk highlight the usefulness of adopting board committees with proposing and consultative functions on CSR issues. The purpose of these committees is to provide a useful contribution to the integration of social responsibility into strategy setting and business model.

\section{Stakeholder Perspective and CSR Committees}

In the last decades, the growing attention for a sound governance in line with the spread of best practices principles and recommendations has promoted the presence of special board committees concerning the management of sensitive issues, linked to significant critical success factors and/or sources of potential conflicts of interest.

Currently, the most common committees all over the world are the audit committee, the nomination committee, and the compensation committee, with monitoring, proposing and consultative functions to support the board in the decision-making processes (OECD, 2015). In addition, boards can decide to establish other ad-hoc committees committed in specific tasks, or permanently devoted to specific narrowly functions.

The governance approach by companies is significantly influenced by the implementation of the principles of social responsibility, stakeholder view, and stakeholder engagement. In particular, the adoption of an inclusive corporate governance approach (Capaldi et al., 2017) focused on stakeholder perspective translates into the growth of the variables driving the decision-making processes towards a balanced satisfaction of wide and different stakeholders' expectations.

Considering this increasing complexity in the definition of sustainable strategies coherent with the company's goals, the establishment of social responsibility or sustainability committees within the board can improve the effectiveness and the 
efficiency of the board's tasks. These committees can have different names (ethics committees, social responsibility committees, conduct committees, environmental committees, sustainability committees, and so on), be various in number and members' characteristics depending on the level of complexity of their issues (as ethics, compliance, environment, etc.), but they are aimed at supporting the RBC (Porter \& Kramer 2011; Burke et al. 2017).

For example, a research on the spread of social responsibility committees in Europe from 2000 to 2016 highlights a different approach to $R B C$ by means of the different names taken by such committees during the years. Until 2010, the term ethics prevailed, due to the big business scandals and pervasive corruption that encouraged companies to recover the confidence of stakeholders mainly by means of ethics and conduct codes. The word 'sustainability' becomes the most recurrent word in the committee names starting from 2010 with a significant growth especially after 2015, also thanks to the statement of the SDGs of UN 2030Agenda (Gennari \& Salvioni, 2019). Such behaviour seems to highlight an evolution from focus on compliance and behavioural correctness towards an approach aimed at making stakeholder perspective more effective.

Such committees, from this point forward called CSR committees, are composed of few directors, at least three members of board for the whole or mostly nonexecutive and independent, according with the corporate governance best practices. The preponderance of independent directors aims at safeguarding the stakeholders' interests because of sign of impartiality and independent judgement ability.

The analysis of 22,916 boards of European companies from 2000 to 2016, shows a gradual increase in the number of companies with CSR committees, from $2.46 \%$ to $6.70 \%$. The presence of such committees appears still to be a novel approach, also considering their detachment from the audit, nomination or remuneration committee and the differences in their functions highlighted by their name (even if sustainability is the most recurrent word, there are also names as welfare, health, environment, anti-corruption, integrity and so on). The number of CSR committees' members is between three and four with a limited incidence of the executive directors. Hence, the composition of such CSR committees reflects the corporate governance best practices suggesting the majority of members are non-executive and independent. Furthermore, together with, or in alternative to, CSR committees within the board, organisational committees devoted to CSR exist with specific tasks and roles about the culture of sustainability and the integration between top decisions and organisational behaviours (Gennari \& Salvioni, 2019). 
CSR committees should have special skills about the management of business in responsible and sustainable way, and they should support the board with suggestions and recommendations in this regard, in order to reduce the risk and maximize the opportunities of value creation in the long time. In other words, CSR committees have proposing and consultative functions for board, so that it can take its decisions with a greater awareness of the relationships among different dimensions of corporate success, (specifically competitive, economic, and socioenvironmental ones) according with a stakeholder perspective. In this regard, the position at the level of corporate governance bodies is important, because of the broad vision at the business level and the participation in decision-making.

This new corporate governance structure, including CSR committees within the boards, is still not widespread, even if some studies support an increasing trend in parallel with the statement of stakeholder perspectives and the increasing number of investors taking into consideration also environmental, social and governance (ESG) factors in their investment assessments.

Spitzeck (2009) focused on the CSR committees of boards belonging to CSR Index in the UK indicating an increasing trend. Eccles et al. (2014) analysed data from 675 US companies and found that the ones placed in the cluster of 'high sustainable' companies adopted CSR committees. Burke et al. (2017) highlighted the increasing number of these committees in public companies over the period 2003-2013. A research by Gennari and Salvioni (2019) considering 22,916 European companies depicted an increasing, even if in unstable, trend from $2.46 \%$ to $6.70 \%$ from 2000 to 2016. In addition, practitioner publications (Calvert Asset Management \& The Corporate Library, 2010; Institute of Business Ethics, 2016) have reported the increasing presence of sustainability committees.

The activities carried out by CSR committees, in addition to the plan of an ethics program, are going to fight corruption, listen to stakeholders, protect the environment, create shared value, reduce risk exposure, and monitor the corporate performance regarding stakeholder engagement and sustainable development. These activities are the prerequisites for a culture of social responsibility to be shared by top levels and organisation, in order to go beyond the mere legal compliance that is still the indispensable base of company's behaviours oriented to stakeholders (Carroll, 1991; Audi, 2012).

Well-structured CSR committees perform the functions of internal coordination, assessment of existing procedures and suggestion of possible improvement changes, support the board's decision-making processes for sustainable goals and strategies. At the same way, the presence of CSR committees lights on the commitment of the board into RBC also to financial markets and other external stakeholders, emphasising the board's attention for social issues more than the situation characterized by the management of social responsibility by other committees or by the whole board. 
Given that CSR committees play a critical role in supporting the board in the $\mathrm{RBC}$, the approach towards them is different depending on the country's culture for social responsibility and industry's characteristics.

The European Union (EU) has been the continent that first became a convert to the CSR movement because of, although innumerable abuses took place along its history, in Europe there have been traditionally more CSR consistent values, norms and perceptions than in other areas of the world. European corporations too have tended to hold stronger and broader approaches to stakeholder relations; and that network is being established to help many companies in sharing and diffusing relevant information about CSR (Mullerat, 2013). In this context, CSR grown at different rhythms, varying country from country and sector from sector.

France is the nation with the highest percentage of CSR committees in the period from 2000 to 2016. France is a unique case in Europe about CSR issue: French State played a leading role in CSR between the mid-1970s and the mid-1980s, achieving changes via legislation and promoting a cultural background that now appears to be the best in the Europe. The French experience teaches that the active government involvement in social responsibility during the last decades created a special attention for this matter also by companies. Regarding sectors' characteristics, the CSR committees tend to be clustered in particular industries where reputation and regulatory risks are more acute. In fact, the presence of such committees emphasises the need to maintain trust relationships with stakeholders, to contrast phenomena with negative impacts on corporate reputation, and to give importance to the environmental impact due to corporate activities. CSR committees tend to gather in banking, assurance, mining, and oil and gas industries (Gennari \& Salvioni, 2019)

In spite of the interest in CSR by the EU businesses and governments, a clear divide of opposite positions has existed. Essentially, the EC took a position of rejecting regulation and putting the emphasis on voluntary measures for business, while the European Parliament, together with NGOs and trade unions, has been demanding mandatory regulation and reporting of corporations' social and environmental impacts and transparency (Mullerat, 2013).

Since the beginning of this Century, several initiatives and contributions from academics, research groups, regulatory commissions and policy makers have highlighted the need for reporting, expressing the integration between financial and non-financial information, and encouraged the debate all over the world (Jensen \& Berg, 2012; Salvioni \& Bosetti, 2014) culminating in the Directive 2014/95/EU (transposed into national legislations from the financial year starting in 2017). Thi Directive obliges certain large undertakings and groups to disclose non-financial information. Considering that these new communication needs are requiring governance structures and processes committed and accountable to stakeholder with reference to economic, social and environmental issues in an integrated way, the establishment of CSR committees as top-position points of reference for different roles and functions differently involved in CSR matters might be of help. 


\section{Conclusions and Emerging Issues}

The development of a multi-stakeholder approach is crucial for creating consensus about long-term sustainable development objectives and results, and it involves significant changes in corporate governance structures and processes.

The greater attention to the ability to activate an ever-wider and more complex network of relationships correlated with the need to achieve positive, lasting relations with all relevant stakeholders increases management complexity and suggests the introduction of CSR committees.

Therefore, the spread of CSR committees is characterizing the two last decades because of the integration between corporate governance best practices and stakeholder perspective.

CSR committees' tasks have been developed according with the corporate approach to social responsibility and its evolution. In a first stage companies tended to divide social and environmental responsibilities from the ethics, this last mainly related to compliance. Then, a wider idea of social responsibility pressed toward a corporate responsibility characterized by compliance and internal ethical culture as essential prerequisites.

The way CSR committees are taking is toward the enhancement of stakeholder perspective and the following $\mathrm{RBC}$ focused on sustainability goals. In fact, the appreciation of stakeholders' expectations, the protection of the environment, the observance of rules, and the sound governance are assets even more important because they can create social and economic value, can reduce the corporate risk and reveal a greater financial sustainability in the long-term.

The increasing attention for CSR and corporate governance structures, as board committees, able to manage effectively the global responsibility in the interest of stakeholders can be promoted by external and internal incentives. External factors, as the increasing interest for social responsibility, sustainability, and accountability by some main international organisations, can play an important role for a change in the corporate approach in favour of stakeholder perspective. At the same time, internal stimulus can be related to the embracement of stakeholder perspective, the considerable corporate complexity and the corporate will to realize a $\mathrm{RBC}$ coherent with the external recommendations; all of these factors require an improvement of decision-making processes and the possible support by CSR committees.

The aforementioned changes in the corporate governance structure imply opening board networks to new profiles, in order to better meet stakeholders' expectation about RBC and to lead company toward sustainability-driven strategies reducing the company's exposure to responsibility failures.

In summary, this article depicts CSR committees as little groups of directors with tasks about CSR issues, in accordance with the members' skills, with the aim to make recommendations to board in order to manage board's activities in a responsible and successful way. In authors' opinion, such committees are supposed to develop in the future and to be under attention of further studies. Future researches will contribute to a better understanding about the encouraging factors for CSR committees' establishment in different contexts, also emphasising the choice of their positioning in corporate governance bodies or within the 
organisational levels. Furthermore, unexplored fields of research concern the best composition and members' profile in order to guarantee a real contribution to responsible governance, and the situations suggesting giving CSR tasks to existing committees instead of constituting an ad-hoc one. In this case, the choice about the committee and the selection of appropriate members' profiles could be studied.

\section{Bibliography}

AccountAbility (2015). AA1000 Stakeholder Engagement Standard. Available at https://www.accountability.org/wp-content/uploads/2016/10/AA1000SES 2015.pdf

Alfiero, S., Cane M., De Bernardi P., \& Venuti F. (2016). Reputational Risk and Disclosure Practices: Comparative Evidence from European Countries, in Cantino, V., De Vincentiis, P., \& Racca, G. (Eds), Risk management: perspectives and open issues. A multi-disciplinary approach, McGraw-Hill.

Audi, R. (2012). Virtue Ethics as a Resource in Business, Business Ethics Quarterly, 22(2), 273291.

http://dx.doi.org/10.5840/beq201222220

Baldarelli, M.G., \& Gigli, S. (2014). Exploring the drivers of corporate reputation integrated with a corporate responsibility perspective: some reflections in theory and in praxis, Journal of Management and Governance, 18(2), 589-613.

http://dx.doi.org/10.1007/s10997-011-9192-3

Barnett, M.L., Jermeir, J.M., \& Lafferty, B.A. (2006) Corporate Reputation: The Definitional Landscape, Corporate Reputation Review, 9(1), 26-38.

Bocean C., Del Baldo M., \& Sitnikov C.S. (2018). Responsible Leadership for Corporate Responsibility, Symphonya. Emerging Issues in Management (symphonya.unimib.it), (1), 139167.

http://dx.doi.org/10.4468/2018.1.11bocean.delbaldo.sitnikov 139

Bosetti, L. (2018). Web-Based Integrated CSR Reporting: An Empirical Analysis, Symphonya. Emerging Issues in Management (symphonya.unimib.it), (1), 18-38. http://dx.doi.org/10.4468/2018.1.02bosetti

Brondoni S.M. (2018). Competitive Business Management and Global Competition. An Introduction, S.M Brondoni. ed, Competitive Business Management. A Global Perspective, Routledge \& Giappichelli, New York-Turin.

Brondoni, S. M. (2014). Global Capitalism and Sustainable Growth. From Global Products to Network Globalisation, Symphonya. Emerging Issues in Management (symphonya.unimib.it), 1, 10-31. http://dx.doi.org/10.4468/2014.1.02brondoni

Burke, J.J., Hoitash, R., \& Hoitash, U. (2017). The Heterogeneity of Board-Level Sustainability Committees and Corporate Social Performance. Journal of Business Ethics, Forthcoming, available at https://papers.ssrn.com/sol3/papers.cfm?abstract id=2902122

Byrne J. (2002). How to fix corporate governance. Business Week, (6), 69-78.

Calvert Asset management and The Corporate Library (2010). Board Oversight of Environmental and Social Issues: An Analysis of Current North American Practice. Available at http://plusweb.org/Portals/0/DandO\%20Material\%202011/Board\%20Oversight\%20of\%20Env\% 20\&\%20Social\%20Issues.pdf

Capaldi, N., Idowu S.O., \& Schmidpeter R. (2017) (Eds) Dimensional Corporate Governance. An Inclusive Approach. Springer International Publishing. 
Carroll, A.B. (1991). The pyramid of corporate social responsibility: Toward the moral management of organizational stakeholders. Business Horizons, 34(4), 39-48.

Cini, A.C. \& Ricci, C. (2018). CSR as a Driver where ESG Performance will Ultimately Matter, Symphonya. Emerging Issues in Management (symphonya.unimib.it), (1), 68-75.

http://dx.doi.org/10.4468/2018.1.05cini.ricci

Del Baldo, M. (2017). Moral and Virtues-based Leadership for Enhancing Integral Ecology, in Jakobsen, O., Zolnai, L., \& and Chatterji, M. (Eds.), Integral Ecology and Sustainable Business, Emerald Publishing Limited: Bingley.

Dima, J. (2008). A Stakeholder Approach to Corporate Social Responsibility: A Fresh Perspective into Theory and Practice, Journal of Business Ethics, 82(1) 213.

http://dx.doi.org/10.1007/s10551-007-9572-4

Dutton, J.E., \& Dukerich, J.M. (1991). Keeping an eye on the mirror: Image and identity in organizational adaptation. Academy of Management Journal, 34, 517-554. http://dx.doi.org/10.5465/256405

Eccles, R.G., Ioannou, I., \& Serafeim, G. (2011). The Impact of a Corporate Culture of Sustainability on Corporate Behaviour and Performance. Working Paper 12-035, Harvard Business School: Boston.

Eccles, R.G., Iannou, I., \& Serafeim, G. (2014). The Impact of Corporate Sustainability on Organizational Processes and Performance. Management Science, 6, 2835-2857.

http://dx.doi.org/10.1287/mnsc.2014.1984

Elkington, J. (1994). Towards the Sustainable Corporation: Win-Win-Win Business Strategies for Sustainable Development, California Management Review, 36, 90 - 100.

http://dx.doi.org/10.2307/41165746

Freeman, R.E. (1984). Strategic Management: A Stakeholder Approach. Pitman Publishing.

Freeman, R.E. \& Dmytriyev, S. (2017). Corporate Social Responsibility and Stakeholder Theory: Learning From Each Other, Symphonya. Emerging Issues in Management (symphonya.unimib.it), (2), 7-15. http://dx.doi.org/10.4468/2017.1.02freeman.dmytriyev

Gennari, F., \& Salvioni, D.M. (2019). CSR committees on boards: the impact of the external country level factors, Journal of Management and Governance, 23(3), 759-785. http://dx.doi.org/10.1007/s10997-018-9442-8

Gorenak, S., \& Bobek, K. (2010). Total responsibility management indicators and sustainable development. International Journal of Sustainable society, 2(3).

Institute of Business Ethics (2016). Culture by Committee: the pros and cons. London: Institute of Business Ethics Pub.

Jensen, J.C., \& Berg, N. (2012). Determinants of Traditional Sustainability Reporting versus Integrated Reporting. An Institutional Approach, Business Strategy and the Environment, 21(5), 299-316.

http://dx.doi.org/10.1002/bse.740

Jones, T.M. (1995). Instrumental stakeholder theory: A synthesis of ethics and economics. Academy of Management Journal, 42 (5), 564-567. http://dx.doi.org/10.5465/amr.1995.9507312924

Kolk, A., Pinkse, J. (2007). Towards strategic stakeholder management? Integrating perspectives on sustainability challenges such as corporate responses to climate change. Corporate Governance, 7(4), 370-378.

Kramer, M.R., \& Pfitzer, M.R. (2016). The Ecosystem of Shared Value, Harvard Business Review, 94, (10), 1-11.

Miller, K., \& Serafeim, G. (Eds) (2014). Leading Sustainable Change, Oxford University Press: Oxford. 
Mosca, F. \& Civera, C. (2017). The Evolution of CSR: An Integrated Approach, Symphonya. Emerging Issues in Management (symphonya.unimib.it), (1), 16-35.

http://dx.doi.org/10.4468/2017.1.03mosca.civera

Mullerat, R. (2013). Corporate Social Responsibility: A European Perspective, The Jean Monnet/Robert Schuman Paper Series 13(6), available at http://aei.pitt.edu/43368/1/Mullerat_CSR_Europa.pdf

OECD (2015). G20/OECD Principles of Corporate Governance. OECD Publishing: Paris.

OECD (2018). OECD Due diligence guidance for responsible business conduct. OECD Publishing: Paris.

Neville, B.A., Bell, S.J., \& Menguec, B. (2005). Corporate reputation stakeholder and the social performance. Financial performance relationship. European Journal of Marketing, 39 (9/10), 1184-1220.

Porter, M., \& Kramer, M. (2011). Creating shared value. Harvard Business Review, 89, 62-77.

Salvioni, D.M., \& Astori, R. (2013). Sustainable Development and Global Responsibility in Corporate Governance, Symphonya. Emerging Issues in Management (symphonya.unimib.it), (1), 28-52.

http://dx.doi.org/10.4468/2013.1.03salvioni.astori

Salvioni, D.M., Bosetti, L. (2014). Sustainable Development and Corporate Communication in Global Markets, Symphonya. Emerging Issues in Management (symphonya.unimib.it), (1), 3251.

http://dx.doi.org/10.4468/2014.1.03salvioni.bosetti

Salvioni, D.M., \& Gennari, F. (2016). Corporate governance, ownership and sustainability, Corporate Ownership \& Control, 13(2), 604-612.

Salvioni, D.M., Gennari, F., \& Bosetti, L. (2016). Sustainability and Convergence: The Future of Corporate Governance Systems? Sustainability, 8, 1203.

http://dx.doi.org/10.3390/su8111203

Salvioni, D.M., \& Gennari, F. (2017). CSR, Sustainable Value Creation and Shareholder Relations, Symphonya. Emerging Issues in Management, (1), 36-49.

http://dx.doi.org/10.4468/2017.1.04salvioni.gennari

Salvioni D.M. (2018). Corporate governance, ownership and global markets, in Brondoni, S. M. (ed.), Competitive Business Management. A Global Perspective, Routledge \& Giappichelli, New York \& Turin.

Spitzeck, H. (2009). The development of governance structures for corporate responsibility. Corporate Governance: The international journal of business in society, 9(4), 495-505. http://dx.doi.org/10.1108/14720700910985034

Visser, W., \& Kymal, C. (2015). Integrated value creation (IVC): beyond corporate social responsibility (CSR) and creating shared value (CSV). Journal of International Business Ethics, $8(1), 29$.

Willard, B. (2012). The Sustainability Advantage, 10th ed. New Society Publishers: London.

Wood, D.J., Logsdon, J.M., Lewellyn, P.G., \& Devenport, K. (2006). Global business citizenship. A transformative framework for ethics and sustainable capitalism, M.E. Sharpe Inc. Armonk. 